\title{
BESZÁLLÍTÓI KAPCSOLATOK ÉS AZ IPARI EGYÜTTMÜKÖDÉS LEHETSÉGES KLASZTEREI A KÖZÉP-DUNÁNTÚLON ${ }^{1}$
}

\author{
(Possible Networks of Suppliers and Industrial Cooperation in \\ the Mid-Transdanubian Region)
}

\section{DŐRY TIBOR}

\section{Az ipari terek és beszállitói kapcsolatok}

A modern ipari terek kialakulásának természetrajza már a nyolcvanas években kiemelten foglalkoztatta a magyar kutatókat is (Enyedi-Rechnitzer 1987, Korompai 1991, Nikodémus 1991). A területfejlesztés oldaláról azonban mindeddig nem merült fel gyakorlati igény arra, hogy valamely hazai térség, régió esetén tisztázni kellene az innovációs terek természeti szerkezetét, a modern ipari átalakulás komplex folyamatát, a rugalmas termelési rendszerek funkcionális térbeli tagolódását.

A nemzetközi szakirodalom gyakran kissé egyoldalúan, a technológia politika globalizációs érvényesülésén keresztül mutatja be az ipari terek kialakulását. Hasonlóképpen háttérbe szorul a multinacionális vállalatok korporatív szerkezetébỏl, vagy ennek ellenpontjaként a kis- és kỏzépvállalkozásokra alapozó regionális önfejlődéséböl következỏ innovációs folyamatok áttekintése is (Nikodémus-Ruttkay 1994).

A regionális tényezők szerepének, a térbeli gazdasági tömörülésekböl adódó gazdasági előnyöknek elsőként Marshall (1979) tulajdonított kiemelt hangsúlyt. Számos térség vállalkozásainak sikertörténete (Szilicium-vőlgy, bostoni 128-as út, M4es folyosó) bizonyítja, hogy a területi integrációs folyamatok elszórt szigetei kiemelkedó gazdasági sikereket képesek elérni. Természetesen a fejlett ipari országok, így az Európai Unió feltörekvő térségei is követendỏ mintaként kezelik a felsorolt "sikerrégiókat". Baden-Württemberg, az olasz "Harmadik Itália", a francia technopoliszok (Grenoble, Montpellier) egymástól gyökeresen eltérő fejlödésinövekedési pályát futottak be. A kis- és középvállalkozások gyors gazdasági növekedésére alapozó gazdaságfejlesztési kísérletek alapján azonban nem lehet egyértelmủ sikeres receptet találni - a tényezỏk rendkívül összetett kombinációja miatt - a folyamatok reprodukálására. A felívelő térségek (Horváth 1993; 1997) számára ugyanis a különbözó eredetũ és természetũ modernizációs elemek szerencsés ötvözeteként bekövetkezó gazdasági siker jelentette a hímevet.

A közgazdasági szakirodalomban ismert, hogy a feldolgozóipari termelés növekedése pozitív hatással van a gazdasági növekedés általános ütemére. Azért mondhatjuk ezt, mivel a feldolgozóipar kibocsátásának növekedése, magán az iparon belül is hatással van a termelékenység növekedési ütemére, valamint közvetve hozzájárul a többi ágazat, így a szolgáltató szektor bővüléséhez is. A feldolgozóipar 
bővülésének hatására egyre gyorsabban szívódik fel a munkaerỏ-felesleg, ill. a növekedés lehetővé teszi, hogy egyre gyorsabban növekedjen a fogyasztásba "átömlesztendő" javak mennyisége. Mindemellett általánosan igaz az is, hogy az iparosítás az egész gazdaságban felgyorsítja a technológiai változásokat (Káldor 1989).

Ha a feldolgozóipari termelés növekedési ütemének okait fürkésszük, akkor a problémát két szakaszban célszerủ számba venni: egyrészt a kereslet forrásainak, másrészt pedig a lehetséges kínálatot megszabó tényezők szempontjából. Ennek megfelelően a kereslet három forrását különböztethetjük meg: a fogyasztást, a hazai beruházások alakulását és a nettó kivitelt.

Káldor szerint számba véve ezen tényezők hatását, a fogyasztás oldaláról azt mondhatjuk, hogy az ipari termelés bövülése reáljövedelem növekedéssel jár egyưtt, ami pedig fokozza az iparcikkek iránti kereslet növekedési ütemét. A kereslet növekedésének fontosabb magyarázatát adják a tỏkeberuházások, ugyanis az általuk elért kapacitásbővülés már önmagában is növeli a szektor termékei iránti kereslet növekedési ütemét, így megteremti a további terjeszkedés ösztönzőit és eszközeit. Ha pedig a kereslet növekedésének harmadik tényezőjét vizsgáljuk, akkor számos, feltörekvó ország tapasztalatára hivatkozva állíthatjuk, hogy a fogyasztási cikkek importhelyettesítési folyamata fokozatosan kiteljesedik, és ezáltal az expanziv fejlödés e szakasza lezárul. A második fázisban az ország egyre növekvő mértékben a feldolgozóipari fogyasztási cikkek nettó exportőrévé válik. Ezt követi a tókejavak importhelyettesítése, majd a fejlödés negyedik szakaszában valószínüsíthető, hogy az ország a tỏkejavak nettó exportőrévé válik.

Kínálati oldalról két meghatározó növekedési korlátot tart nyilván a szakirodalom, a termékkorlátot és a munkaerôkorlátot. Az ipari szektor a termelés bövülésével egyre több, a feldolgozóiparon kívül elöállított terméket és szolgáltatást vesz fel, azonban ezzel párhuzamosan - az importhelyettesítés ellenére is - lényegesen megnövèli a behozatali igényt, ami a fizetési mérleg romlását eredményezi.

A leírt elméleti közgazdaságtani fejtegetések aktualitását adja a KözépDunántúlon megfigyelhető jelentős mértékủ ipari termelés - és ezzel párhuzamosan az export - bővülés, a beruházási tevékenységek kiemelkedó mértéke, ill. a munkaerő iránti kereslet fokozódása. Ha a növekedés előbb felsorolt tényezőinek hatását elemezzük, megállapítható, hogy a Közép-Dunántúlon a gazdasági növekedés szinte kizárólagos "motorja" az exporthányad tartósan magas és egyre növekvő értéke. A folyamat vezérlésében elenyésző szerepet játszik a lokális, regionális fogyasztás, ill. a hazai beruházások aránya is csak törtrésze a külföldi vállalati központokból irányított befektetéseknek. A régió gazdasági sikereit egyértelmüen az új üzemek kibocsátásának egyre fokozódó üteme, ill. ebben a néhány vállalkozásban (számuk nem több egy tucatnál ${ }^{2}$ ) elért termelékenység növekedés jelenti. Ezen vállalkozások beruházásai miatt a térségben szinte a természetes ráta közelébe süllyedt a munkanélkủliek száma, ill. a munkaerő iránt megmutatkozó kereslet szlukségessé teszi, hogy egyre nagyobb körzetből ingázzanak naponta munkások százai. Sőt az egyes szakmák iránti igény már-már a fejlődés gátjává válhat.

A térségben megfigyelt jelenségek nagyvonalú makrogazdasági elemzésével megállapítható, hogy a regionális gazdaság bővülésének tendenciája tartósan pozitív, és a megkezdett, valamint a befejezett beruházásoknak köszönhetően valószinüsíthetó a terület gazdaságának további fejlődése is. Ezen tanulmány - divatos szóval élve - a 
fenntartható fejlödés feltételeinek vizsgálatával, és ezen belül is kiemelten a termelés bövülés más gazdasági szektorokra való kiterjesztésének lehetöségeivel, a hazai beszállítási arány bövítésének lehetséges útjairól szól.

A Közép-Dunántúl Regionális Fejlesztési Stratégiája keretében folytatott gazdasági-társadalmi vizsgálat tapasztalatai alapján ugyanis jogosan feltételezhetjük, hogy ebben a térségben is tapasztalhatók olyan jelek, gazdasági eredmények, melyek hosszabb távon "ipari körzet" kialakulásához vezethetnek. Ez ma még természetesen csak kiinduló hipotézis, és számos tényezö, ill. éppen a nevezett stratégiára épülő programok járulhatnak hozzá leginkább a Közép-Dunántúlon "ipari körzetek" létrejöttéhez. A nemzetközi tapasztalatok ismeretében azonban felhívjuk a figyelmet egyúttal arra is, hogy a hosszú távú és tartós gazdasági sikerhez a térségben található vállalkozások (hazai és külföldi nagy-, valamint kis- és középvállalkozások) között az együttmüködési és beszállitói kapcsolatok rendkivül intenzív fejlödésének kell végbemenni a kívánt cél eléréséhez.

Ennek a lehetséges forgatókönyvnek valamifajta hátteret kölcsönözve feltérképeztük a térség azon vállalkozásait, amelyek kiinduló hipotézisủnk szerint beszállítói hálózatok meghatározó vállalkozásai lehetnek. Annak tudatában tettük ezt, mivel közismert, hogy a beszállítói kapcsolatoknak jelentös szerepük van a technológia transzferben, az innovációk diffúziójában. Egyúttal ez a kapcsolatrendszer a megrendelö igényének kielégitésén túl is hozzájárul a beszállitó vállalat műszaki, vezetési és szervezési színvonalának emeléséhez. Ez pedig mind a régió, mind Magyarország fejlödése szempontjából különleges fontosságú. Bár az igazsághoz tartozik, hogy a piacon maradáshoz az egyes beszállítóknak egymással is komolyan versenyezniük kell, valamint magas minöségi követelményeket kell teljesíteniük ${ }^{3}$.

Napjainkban sok szó esik a beszállitók szerepének növeléséról (a Gazdasági Minisztérium által koordinált beszállítói programról), a hazai hozzáadott termelési érték arányának növeléséról. Ebben a vonatkozásban azonban sok esetben nem egészen világos, mit is takarnak ezen vállalatközi kapcsolatok. Az Európai Unió Statisztikai Hivatala definíciója szerint,

- a beszállítói kapcsolatokban a megrendelö részt vesz a termék kialakitásában, a gyártó számára részletes technikai dokumentációt vagy meghatározott specifikációt aĺ.

- a termékek forgalmazásáért a megrendelö a felelös olyan módon, hogy - a beszállítónak nincs joga a szerződés lejártáig a terméket más fogyasztó számára értékesíteni és/vagy

- a termék beépítése után a termék a megrendelö védjegyét hordozza.

Úgy gondoljuk, hogy a területfejlesztésben érdekeltek (intézmények, gazdasági szervezetek, stb.) számára egyértelmú a beszállítói kapcsolatok szerepének megitélése. A területi gazdaság érdekeit az szolgálja ugyanis leginkább, ha a termékek, szolgáltatások elóállításához helyben, de legalábbis az adott régióban megtalálhatók a szükséges alapanyagot, félkész terméket beszállító vállalatok. A kutatók álláspontja szerint a Magyarországon letelepedett multinacionális vállalatok akkor nem válnak "sivatagi katedrálisokká", ha sikerül nekik helyi (a régióban, de legalább Magyarországon letelepült) beszállitókat, alvállalkozókat találniuk, s ezáltal beágyazni, a helyi gazdasághoz sok szállal kötni őket. Szerencsés esetben tehát a termeléshez szükséges anyagokat, szolgáltatásokat, vagy azok egy részét helyben ké- 
pesek lesznek beszerezni. Ez már csak azon múlik, hogy sikerül-e az adott feladathoz kötődő, olyan vállalkozást találni, amely képes lesz kiváltani (tisztán nyereség elven hozott, profit érdekeket szem elött tartó döntés alapján) korábbi beszállitóját ${ }^{4}$. Ha vannak, vagy lesznek olyan hazai vállalkozások, akik aktív beszállitóvá képesek válni, és lehetöleg nagy számban, vagy kulcsfontosságú területeken lesznek ilyenek, akkor már nem kell arra gondolni, hogy a külföldi tulajdonos önkényes döntése alapján áttelepíti gyárát még olcsóbb bérủ országba. Ekkor ugyanis már neki is érdeke lesz Magyarországon maradni, hiszen vállalkozása annyira "beágyazódik" a hazai, a regionális gazdaságba, hogy csak újabb nagy összegủ beruházások, kockázatok árán lenne képes új telephelyet nyitni a világ más tájản.

A fejlesztési stratégia készítöiként rendkívül fontosnak érezzük ezen gondolkodásmód elsajátítását, hiszen ennek birtokában lehet majd elérni, hogy a felelös döntéshozók, kormányzati, önkormányzati szakemberek megfelelően kezeljék a beszállításokkal kapcsolatos programokat, és mindent elkövessenek a befektetés-ösztönzés feltételrendszerének kialakításakor mind helyi, mind regionális szinten.

Az Európai Unióban súlyának megfelelően kezelik a beszállítói kapcsolatokat és rendszereket, és a kifejezetten erre irányuló program kiemelt célnak tekinti

- a beszállitói piacokra vonatkozó ismeretek bővítését,

- a minóségtanúsítási és szabványosítási eljárások harmonizálását,

- a nagy- és a kisvállalatok közötti együttmüködés elősegitését.

Az Unió kezdeményezései három fö irányt jelentenek:

1. a beszállítók számára kedvezö gazdasági környezet megteremtése az egységes európai piac perspektívájával,

2. a fö- és alvállalkozók (beszállitók) közötti információ és kommunikáció javitása,

3. az európai beszállítások elömozdítása "harmadik országban".

$\mathrm{Az}$ OECD országok sikeres tapasztatai is azt mutatják, hogy az egyes régiók dinamikus fejlödésének kulcsát többek között a kis- és középvállalkozások jelentik. A régiók dinamikus fejlődésének feltétele, hogy a terület vállalkozásai szoros együttmüködési, beszállítói kapcsolatokat alakítsanak ki egymással, a kis- és középvállalkozások és a nagyvállalatok között alakuljanak ki beszállítói hálózatok, a vállalkozások fejlödésének alapját innováció-orientált stratégia képezze, intenziv kutatásfejlesztési $(\mathrm{K}+\mathrm{F})$ tevékenységet végezzenek, és vásároljanak $\mathrm{K}+\mathrm{F}$ eredményeket.

A magyar nemzetgazdaságon belül a gazdaság fejlödése szempontjából két, egymástól jelentősen eltérỏ és különböző út rajzolódik ki (Matolcsy 1997). Az első döntöen a külföldi müködő tőke innovációs, ill. a versenyképességet erősitő és integrációs szerepére épit, mig a második lehetséges út emellett egyenlöen épit a hazai tulajdonú vállalkozásokra, ezeken belül is kis- és középvállalkozói szektorra. Az elsö utat az innovációs-gócpontok kiemelkedése (Budapest és térsége, ÉszakDunántúl), a gócokban megnövekedett termelékenység, a regionális különbségek növekedése, valamint fokozódó pénzügyi egyensúlyhiány jellemzi. A második út az innovációs gócok összekapcsolását, hálózatokkal való körülvételét, valamint a hazai tulajdonú, megerösített kis- és középvállalkozások által teremtett új munkahelyek segítségével megoldandó a foglalkoztatási probléma megoldását körvonalazza. 
Beszállitói kapcsolatok és az ipari együttmüködés lehetséges klaszterei a Közép-Dunántúlon.

Tér és Társadalom, 12. 1998. 3. 77-92. p.

\section{Beszállitói kapcsolatok a rendszerváltozás után}

A hazai beszállítások helyzetét elemezve azt mondhatjuk, hogy a rendszerváltozás utáni folyamatok a hazai piacon belüli, az amúgy sem túlságosan kiterjedt beszállítói kapcsolatokat több szempontból is kedvezőtlenül befolyásolták. Ezek közül is kiemelkedik három olyan körưlmény, ami hátrányos helyzetbe hozta a beszállitiókat az amúgy is elterjedtebb bérmunka alkalmazásával szemben (Bagó 1991):

1. A beszállitói kapcsolatokban leginkább érintett ágazatokat az ipari termelés visszaesése különösen súlyosan érintette, termékeik jelentős hányadát elsősorban ugyanis a KGST piacokra szállították.

2. Méretének és létszámának védelme érdekében sok nagyvállalat számos korábbi partnerkapcsolatát felszámolta, ismét "autarchiára" törekedve olyan beszállítóit is leépítette, melyek a specializáció, a gazdaságosság, a versenyképcsség szempontjából hasznosak voltak számára.

3. Az import gyors (túlzottan gyors) liberalizálása ugyancsak jelentős mértékben hozzájárult a belfôldi beszállítók kiszorulásához.

A tartósabb beszállítói kapcsolatok kialakulásához stabil gazdasági környezet szükséges. A rendszerváltozást követô első időszakban a vállalatok vezetése - a privatizációra és az államot képviselö, tulajdonosi szerepkörben fellépő intézmények nehezen elörelátható lépéseire várva - a legtöbb esetben rendkívül bizonytalan körülmények kőzött folytatta munkáját. Ugyanakkor a korábbi korlátok eltörlése, a külfơldi tőke, a multinacionális vállalatok, a közös vállalkozások bővítették a beszállitások lehetóségeit.

A jövő tendenciáit elemezve azt mondhatjuk, hogy a magyar, így a régióban található kis- és középvállalkozások sem számíthatnak tehát arra, hogy azonnal - de még középtávon sem - a beszállítói piramis elökelö szintjére kerülhetnek. Kezdetben ugyanis nem kapnak fejlesztési megbizásokat, illetve az így elért kvázimonopolhelyzet következtében hosszú távon is biztos megrendeléseket. Amire viszont joggal törekedhetnek: a közvetlen beszállitók alvállalkozói lehetnek, $\mathrm{s}$ ennek megfelelö́n kapcsolódhatnak a széles nemzetközi tapasztalatokkal rendelkezö vállalatok rendszereihez. Azonban az igazán kritikus, müszakilag igényes alkatrészek, például a motor alkatrészei esetében még erre is csak akkor van esélyük, ha jól kiépitett piaci kapcsolatokkal rendelkezỏ külföldi partnert tudhatnak maguk mellett, mögött.

A korábbi állapothoz képest természetesen ez a jövőkép is nagy elórelépést jelent, hiszen ezeknek a beszállitóknak is el kell sajátítaniuk az igényes vevők által megkövetelt termelés-szervezési, technológiai módszereket. Gyakran új termékeket és termelési eljárásokat kell bevezetniük, amihez szakértői és pénzügyi segítséget is kapnak partnereiktől. Ezek a változások egyértelmúen az új termelési rendszerek magyarországi terjedését, a hazai modernizációt szolgálják, ill. hosszú távon segítenek elérni azt, hogy a magyar vállalatokat is egyenrangú partnerként kezeljék a nemzetközi piacokon.

A korábbi Ipari és Kereskedelmi Minisztérium ${ }^{5} 1994$ decemberében készített, "Ipari struktúraváltozások elemzése" c. tanulmánya alapján állítható, hogy a magyar feldolgozóipar legtöbb ágában (kivétel a ruházati ipar!) kisebb a beszállitások szerepe és súlya, mint a fejlett piacgazdaságokban. Az ipari termelés rendszerváltozást követó nagy visszaesése nyomán a korábbi beszállitói kapcsolatok jelentős részét 
felszámolták; új kapcsolatok azonban csak kisebb számban jöttek létre, elsösorban az autóalkatrész-gyártás és a ruházati ipari bérmunka területén.

A beszállítók kiválasztását sok szempont befolyásolhatja, amelyek között kitüntetett helyen található a magas szintü és tartósan azonos minőség, ill. a pontos szállitási feltételek (just in time) (1. táblázat).

\section{TÁBLÁZAT}

A beszállítók kiválasztásában szerepet játszó tényezők rangsorolása (Priority of Factors in Selection of Suppliers)

\begin{tabular}{|l|c|c|c|c|}
\hline \multicolumn{1}{|c|}{ Tényezö } & $\begin{array}{c}\text { Gép- } \\
\text { gyártás }\end{array}$ & $\begin{array}{c}\text { Híradás- } \\
\text { technika }\end{array}$ & $\begin{array}{c}\text { Közúti jármủ- } \\
\text { gyártás }\end{array}$ & Ruházati ipar \\
\hline Minöség & 1 & 1 & 1 & $1-2$ \\
\hline Szállítási feltételek & 2 & 3 & $4-5$ & $3-4$ \\
\hline Ár & $3-5$ & 5 & 2 & $1-2$ \\
\hline Rugalmasság & $3-5$ & 2 & $4-5$ & $3-4$ \\
\hline Fejlesztői potenciál & $3-5$ & 6 & 6 & 6 \\
\hline Szakmai hírnév & 6 & 4 & 3 & 5 \\
\hline
\end{tabular}

Megj:: 1 - alapvetó fontosságú, 6 - kevésbé fontos

Forrás: Román (1995): Beszállítåsok a feldolgozóiparban

\section{Vállalati megkérdezések tapasztalatai}

A bevezetöben ismertetett elméleti felvetések igazolására empirikus vizsgálatot kezdeményeztünk a Közép-Dunántúl közép- és nagyvállalatai körében. Célunk az volt, hogy a beszállítások iránti keresleti oldalt "megszondázzuk". Ennek keretében választ szerettünk volna kapni azokra a kérdésekre, hogy milyen tényezök megléte esetén lehetne a térség hazai és multinacionális nagyvállalatainak több hazai beszállítója, ill. milyen tapasztalataik vannak a megkérdezett gazdasági szervezeteknek a gazdasági együttmúködés területén.

A felmérésbe olyan termelő vállalkozásokat igyekeztünk bevonni, amelyek alaptökéje meghaladja a 100 millió forintot és legalább 100 föt foglalkoztatnak. Ezeknek a kritériumoknak megfelelö cégeknek közel egyharmada különböző okokra hivatkozva elhárította megkeresésünket. Végull 27 vállalkozásnál ${ }^{6}$ lezajlott interjú tapasztalataira hagyatkozva készitettük el elemzésünket ${ }^{7}$.

\section{Beszállítói kapcsolatok}

A beszállítói kapcsolatok vizsgálata során - a közép-dunántúli régióra koncentrálva - súlyponti kérdés volt, hogy mennyiben nó a regionális piac jelentősége a cégek beszerzési és értékesítési kapcsolataiban. A multinacionális cégek esetében azt tapasztaltuk, hogy a beszerzés és értékesítés területén döntően kulföldi partnerekkel (az anyavállalat kulföldi üzleti partnereivel) állnak kapcsolatban, míg néhány korábbi állami vállalat (pl. az IKARUS MÓRI ALKATRÉSZGYÁRTÓ Kft [továbbiakban IMAG.]) a rendszerváltás után is megörizte korábbi belföldi kapcsolatait, de a nyugat felé történỏ nyitás itt is meghatározóvá vált. A multik esetében az értékesítési piac szinte $100 \%$-át külföldi partnerek uralják, ezen belul a német és az amerikai vállalatok dominanciája jellemző. Ez a tendencia a beszerzési, beszállitói kap- 
csolatok esetében is fennáll, bár elenyészö mértékben ugyan, de belföldi beszállítókkal is rendelkeznek. Ez a termeléshez közvetlenül nem kapcsolódó szolgáltatások igénybevételét jelenti: könyvelöi, könyvvizsgálói feladatok elvégzését, banki szolgáltatások igénybevételét, üzemi étkeztetést, órzö-védỏ szolgáltatást, egyes esetekben a karbantartást is helyi, vagy a térségben található cégeken keresztül oldják meg.

Számos ipari nagyvállalat (pl. a Magyar Alumínium Rt, az ALCOA-KÖFÉM) a Közép-Dunántúlon kialakulófélben lévó hálózattal rendelkezik. A régióban új beruházást tervez a jövőben az ALCOA, ALCOA Automatic néven. A jövőben, - elözetes tervek szerint - Tatabányán fogják gyártani az AUDI számára az A6-os modell alumínium karosszéria-elemeit. A felhasznált alapanyag szintén az ALCOAKÖFÉM-tól fog származni.

Valódi beszállítói hálózatok kialakulását mutatja, hogy az egyik telephely termékét használja fel a másik üzem alapanyagként. Megpróbálják az üzemek közötti együttmükődést fejleszteni, ami az információs rendszer, valamint a munkaerögazdálkodás hatékonyabbá tételét is jelenti. A régióban letelepedett multinacionális vállalkozások és a tőkeerơs hazai nagyvállalatok (VIDEOTON, MAL) egyik célja közép-európai bázisok létrehozása, a már müködők mellett.

$\mathrm{Az}$ egy vállalaton belüli hazai telephelyek közötti kooperációs kapcsolatokon kívül a külföldi érdekeltségủ vállalatok részéröl is igény mutatkozik a belföldi beszállítói kapcsolatok erösítésére. Az AFL (Alcoa Fujikura Limited) például folyamatosan keres magyar beszállítókat együttmüködés céljából, de eddig nem talált megfelelỏ partnert igényei kielégítésére. Megpróbálták néhány környékbeli kisvállalkozással felvenni a kapcsolatot, de ez mind a mai napig eredménytelen maradt. Ennek oka, hogy az eddig vizsgált lehetséges beszállítók minőségben, de föleg mennyiségben nem tudtak megfelelni a cég elvárásainak. Az autóipari tevékenységet folytató vállalatoknál a minőségi követelményeket a nemzetkőzi minőségügyi szabványoknak való megfelelés jelenti. A mennyiségi követelményekhez való alkalmazkodás legföbb akadályát a környező vállalkozások tőke- és kapacitáshiánya jelenti.

Sok vállalat konkrét elvárásokat fogalmazott meg a hazai alvállalkozókkal szemben (ezek a mai gazdasági életben általános érvényünek tekinthetök):

- mennyiségi követelmények,

- minőségbiztosítási rendszer,

- megfelelö technológiai színvonal, számítástechnikai rendszer,

- menedzsment, szervezési-vezetési ismeretek,

- megfelelő szakképzettség,

- elö- és utókalkuláció,

- önállóság.

A megkérdezett vállalkozások tapasztalatai alapján a felsorolt követelmények teljesítése általában problémát jelent a beszállítóvá igyekvő (másod-, és harmadvonalas) cégeknek. A megrendelö cég segítségével lehetőség nyilik a korszerủ minöségbiztositási rendszerek bevezetésére és a megfelelö információs rendszer kiépítése is alapkövetelmény. Mindennek költségét természetesen a beszállitónak kell vállalnia, ami sok esetben meghaladja a potenciális beszállítók lehetőségeit. Azok a problémák, melyeket az alvállalkozónak önállóan kell megoldania a megfelelő szakképzettség, gazdálkodási, menedzsment és marketing ismeretek megszerzése, a folya- 
matszervezési eljárásokban való jártasság területén jelentkeznek. Így meglátásunk szerint tehát ezeken a területeken lenne szükség jelentösebb állami, önkormányzati szerepvállalásra.

A megkérdezések során felvetödött, hogy piacképes-e a magyar vállalkozói mentalitás? Ugyanis tapasztalatok szerint a hazai vállalatok nem fektetnek kellö hangsúlyt a vezetöképzésre, nehézséget okoz számukra a piaci igényeknek való megfelelés, alkalmazkodás, valamint a gyorsan változó feltételek rugalmas kezelése. Ezen hiányosságok ellenére azt mondhatjuk, hogy jó irányba fejlődik a hazai vállalkozók hozzáállása, üzleti ismerete, s nem sok szégyellnivalójuk van a sokkal kedvezőbb keretfeltételek (elsősorban makrogazdasági) mellett dolgozó európai versenytársaikkal szemben.

A multinacionális cégeknél megfigyeltekkel ellentétben, a mintában szereplő hazai vállalatok (pl. VIDEOTON, az IMAG) jelentỏs belföldi beszállítói kapcsolatokkal rendelkeznek. Az IMAG tradicionális magyar vállalat, s így ismeri a középdunántúli régióban fellelhető gazdasági-piaci lehetőségeket, és ezek kihasználására törekszik. Ebből következik, hogy a régión belüli piac egyre inkább meghatározóvá válik számos cég számára, és jellemzően székesfehérvári, móri és a környező, alkatrészeket szállító kisvállalkozásokkal kooperálnak. Például az IMAG megítélése szerint ezen beszállitói kör bövitésének akadálya, hogy a kisvállalkozások nehezen képesek megfelelni a versenyfeltételeknek. A tökehiány nemcsak a termelés volumenét, hanem a technológiai és a humán fejlesztést is determinálja.

A vizsgált vállalatok közül a VIDEOTON és az IMAG az egyetlen, melyröl elmondható, hogy felismerte a regionális piacok jelentőségét, annak kiaknázásából származó előnyöket (föleg a szállitási költségek megtakaritása révén). Az IMAG tervei között szerepel ezen piaci szegmens erösítését szolgáló esztergomi beruházás is. A SUZUKI üzem közelében egy összeszerelö uzemet szándékoznak létesiteni, melynek célja a szállitási költségek megtakarítása. Eddig a készre szerelést a móri üzem hajtotta végre, ezt a funkciót veszi majd át az új telephely, kihasználva azt, hogy az üléseket külön részenként szállítva kisebb a helyigény, mint a kész ülések szállítása során. Így az elmélet és gyakorlat találkozásának példájaként, egyazon város lesz az összeszerelés és az értékesítés helyszine.

\section{Szakképzés, munkaerō gazdálkodás}

A munkaerö fejlesztésben, a megfelelö mennyiségủ és minöségú (azaz képzettségü) munkaerő rendelkezésre állásában valamennyi cég közvetlenul érdekelt, amit jól érzékeltet a vállalatok aktív kezdeményező hozzáállása, magatartása ezen a terưleten.

Az olcsó, viszonylag jól képzett hazai munkaerỏ a külföldi tulajdonú cégek fó telepitési tényezöi közé tartozik, így a munkaerō-gazdálkodás, a humánpolitika kezdettől fogva nagy hangsúlyt kap a vállalatok belsỏ életében, gazdálkodásában. A vállalatok letelepülésưk utáni legfontosabb feladatai közé tartozott a megfelelö munkakultúra és munkamorál meghonositása, a magyar munkaerö mintegy "hozzáidomítása" az elvárt követelményekhez (két ill. három műszakos munkarend, ill. folyamatos müszakok elfogadtatása magasabb bérezés fejében, amit egyébként a nyugati szakszervezetek elutasitanak). 
A munkaerő gazdálkodás területén ma a legégetőbb probléma a Mór és Székesfehérvár térségében jelentkező munkaerőhiány. A potenciális munkaerő kínálat terén a multinacionális cégek napjainkban már versenyezni kényszerülnek, igy alakulhatott ki az a helyzet, hogy a vállalatok 40-50 km-es körzetből kénytelenek dolgozóikat az üzemekbe szállítani.

A munkaerőképzéssel, szakképzettséggel kapcsolatban valamennyi cég konkrét elvárásokat fogalmazott meg. Szinte mindegyik vállalat nagy gondot fordít a saját munkaerő továbbképzésére, elsỏsorban az idegen nyelvek, valamint a minőségbiztosítás területén.

A vállalatok által megjelölt hiányszakmák:

- logisztikai és minöségbiztositási mérnökök,

- tapasztalatokkal rendelkező pénzügyi szakemberek,

- hegesztök, gépészek és gépkezelök,

- öntőmunkások.

\section{Fejlesztések, beruházások}

$\mathrm{Az}$ általunk vizsgált cégeknél az volt az általános tapasztalat, hogy a vállalatok folyamatosan, a piaci igényekkel párhuzamosan hajtják végre fejlesztéseiket, amelyek legtöbbször kapacitásbővitỏ beruházások, mennyiségi és minőségi fejlesztések és egyúttal a vállalatközi együttmüködések folyamatos és szoros stratégiai kapcsolatok fenntartását feltételezik.

A fejlesztések, beruházások üteme azt tanúsítja, hogy a felkeresett vállalkozások dinamikus expanziót hajtanak végre, szinte mindenütt (ahol átláthatók a tulajdonviszonyok, ill. szakmai befektetők a cég tulajdonosai) nagymértékủ beruházási tevékenység tapasztalható.

A felkeresett cégeknél megtörtént vagy éppen folyamatban van a minőségbiztosítási rendszerek fejlesztése, tanúsítása, ami egy "valamire való" beszállító lételemének tekinthető. A QS 9000, az ISO 9000-9003, valamint a VDA (amerikai autóipari szabvány) feltételeinek az elmúlt év(ek)ben a cégek eleget tettek, a legújabb célként már néhol kiépités alatt áll az ISO 14001, az ISO 9000 környezetvédelmi követelményekkel kibővített változata is.

\section{Önkormányzatokkal való kapcsolatok}

Valamennyi cég pozitívan ítélte meg a helyi önkormányzattal való kapcsolatát. Az önkormányzat elsősorban a beruházáshoz szükséges terület biztosításában, ill. az infrastruktúra megteremtésében játszott fontos szerepet.

A helyi adó mértékét többségük (Székesfehérvár gyakorlatát leszámítva) elfogadhatónak tartja, hiszen az önkormányzat nem veti ki a maximális kulcsokat a helyi termelökre. A bürokrácia - mint mindenütt - itt is problémát jelent, de az engedélyeztetési eljárás egyszerüsítése terén az önkormányzatok jó úton haladnak.

A vállalatok önkormányzati fejlesztési támogatást kevésbé vettek igénybe, ennek oka, hogy nem megfelelő mennyiségủ az erre elkülönített pénz, és az eljárás túlzottan hosszadalmas. A nagyvállalatok többsége nem is elsősorban pénzügyi támogatást vár az önkormányzattól, sokkal inkább az infrastruktúra és a telepủlési környezet javitását, szociális szolgáltatások, ill. az oktatási intézmények fejlesztését a letelepülni szándékozó munkaerỏ számára. Nagy segitség lenne az új munkatársak szá- 
mára a bérlakás kínálat bövítése, újabb lakások, bérlakások épitése, mely a megkérdezettek szerint szintén ơnkormányzati feladat.

\section{Kamarák szerepének megitélése}

A kamarák feladata többek között a vállalatok tevékenységének elősegítése, a cégadminisztráció, a vállalkozások letelepedésének elősegítése, fejlesztési pályázatok kiírása és elbírálása. Ennek tükrében a kamarák tevékenységének megitélése egyértelmüen negatív. Úgy tünik, ma a kamarák nem képesek ellátni tulajdonképpeni feladataikat. Ezt mutatja a vállalatok által adott kedvezötlen értékelés is: többségük egyenesen "kidobott pénznek" tartja az éves kamarai dijat, véleményük szerint az érdekvédelmi szervezetek tevékenységét alacsony hatékonyság és erôs bürokrácia jellemzi. A vállalati kezdeményezéseknek nem, vagy csak késlekedve tesznek eleget. Például a VIDEOTON beszállitói programját a területi kamarák (a megyei kereskedelmi és iparkamarák) nem mindegyike találta felvállalandó feladatnak. A VIDEOTON illetékes igazgatója szerint beszállítojává váláshoz sok hazai kis- és középvállalkozásnak van esélye, és a beszállitói fórumok szervezésével a Kamarák saját "ázsiója" is növekedhetne.

\section{Az EU csatlakozás hatása}

Magyarország EU csatlakozását a vállalatok mindenképpen kedvezőnek tartják a régió fejlődése szempontjából. A régiót versenyképesnek ítélik, mely "megállja a helyét" az új, megváltozott viszonyok között is, ill. képesnek találják további fejlödésre. A csatlakozástól elsősorban a közlekedési kapcsolatok további javulását, egyszerüsődését ill. bizonyos mértékủ migrációs folyamatokat várnak.

A csatlakozás elönyeit, hátrányait összevetve, az integrációt a cégek általában pozitívan élik meg. A várható előnyök között említik a vámeljárás, adminisztráció egyszerüsödését, ill. azt, hogy már nem lesz sziikség vámszabadterületekre. (A vizsgált cégek közül többen vámszabadterületen termelnek.) Elsősorban a multinacionális vállalatoknál mérvadó az a követelmény, hogy a gyártott termék (ill. a hozzá felhasznált alapanyag) 60\%-ának EU tagországból kell származnia, mert csak így minősül EU terméknek, így esik kedvezöbb vámtarifa alá. Ez egyik lẻnyeges akadálya a magyar beszállítói kör bővítésének. A csatlakozás másik, elkerülhetetlen, és a cégek oldaláról hátrányos következménye viszont a munkabérköltségek növekedése.

\section{A felmérés tapasztalatainak összefoglalása}

A Közép-Dunántúlon formálódó ipari övezet, körzet legfontosabb közös jellemzője, hogy valamennyi idetelepült, külföldi nagyvállalat tevékenysége - valamilyen módon - az autóiparhoz kapcsolódik. A vállalatok az autógyártás különbözỏ részterületeit, eltérö mozzanatait végzik tevékenységük keretében, így nem feltétlenül jelentenek egymás számára potenciális versenytársat.

Az ugyanazon iparághoz való kapcsolódás, a vállalatok közti verseny részleges hiánya, illetve a cégek viszonylag kis területen (egy-egy településen belüli, mint pl. Mór, Székesfehérvár, Veszprém, Tatabánya) való koncentrációja prognózisunk szerint közép, de inkább hosszú távon lehetővé teszi egy, az autóipari termelésre specializálódott csoport ("klaszter") kialakulását a Közép-Dunántúlon belül. Ehhez 
azonban szükséges a vállalatok közötti együttmüködés intenzitásának további növelése, ami ma még kevésbé jellemző. Egy-két kivételtól eltekintve, nem találtunk példát egyazon városon vagy régión belüli kapcsolatkeresésre. A vállalatok szemléletét erőteljes külpiaci-orientáció, a szomszéd cégekkel való viszonyt a "békés egymás mellett élés" politikája jellemzi. Természetesen ez érthető is, hiszen a vállalatok, különösen a multinacionális cégek, elsősorban a külföldi értékesítési piacokat keresik, a relatív kis felvevö-képességủ magyar piac mellett és fỏ céljuk a világpiaci részesedés növelése.

Ma még nem óriási, de érezhetöen fokozódó probléma a munkaerö megszerzése, melyben az egyes vállalatok egyértelmủen egymás versenytársai. A multiknál a munkaerỏ gazdálkodás - a magas minőségi és teljesitmény követelmények fenntartása - életbevágó fontosságú, a keleti nyitás egyik meghatározó tényezője. Mivel valamennyi vállalat stratégiája a dinamikus növekedés, gyaníthatóan megvannak a belső, endogén fejlödés lehetöségei. Így a vállalkozások növekedését, tevékenységi körük szélesítését hátráltathatja a térség szükös munkaerö kínálata, ami egy olyan közös probléma, amely közös konfliktuskezelést igényel minden érdekelt bevonásával.

\section{A Közép-Dunántúlon kirajzolódó ipari körzet lehetséges klaszterei}

Nemcsak tudományos kérdés, hogy egy adott térségben a gazdaság mely klaszterei, csoportjai jelennek meg, hanem a régió döntéshozói (mind a magán, mind a közösségi szektor) számára is segítséget nyújthat ezen megközelítés. Ennek során a területi gazdaság nem csak ágazati megközelítésben képezi a vizsgálat tárgyát, hanem a klaszterek meghatározásával lényegében olyan támpontot ad a területi szereplöknek, melynek segítségével könnyebben hozhatnak ủjszerü stratégiai és taktikai döntéseket, ill. új fejlödési pályára terelhetik a regionális gazdaság fejlődését (Hrubi 1994).

$\mathrm{Az}$ ágazati klaszterek - Lasuén szerint - térben is koncentrálódnak, hiszen a technológiai változások sorozataként fellépó gazdasági növekedés eredményeképpen fokozódnak a külső és belsó megtakarítások, a vállalkozások közötti kapcsolatok révén pedig bövülnek a piaci és a termelési komplementer hatások. Az innovációkon alapuló fejlödési folyamatban az ágazati klaszterek szoros egymásra utaltsága egyưutt jár az urbanizációs folyamat által gerjesztett regionális klaszterek kialakulásával, ill. megteremtik a regionális növekedés feltételeit (Rechnitzer 1994).

A következö néhány pontban azokat a klasztereket tárgyaljuk röviden, amelyek az empirikus, vállalati megkérdezéseken alapuló, valamint statisztikai mutatók kiértékelésén nyugvó kutatásaink szerint a Közép-Dunántúlon kirajzolódni látszanak, ill. nézetünk szerint a jövőben megerősödhetnek.

Autóalkatrész- és gépjármüipari klaszter

Ezen klaszter létrejötte tünik a legvalószínübbnek a térségben, hiszen az autóalkatrész gyártásnak (pl. Bakony Müvek) és a gépjármüiparnak (pl. Ikarus) itt már a rendszerváltozás elött is komoly hagyományai voltak. Az ágazat szerepének fokozódását azonban a kilencvenes években letelepedett nyugati befektetök megjelenésével bizonyíthatjuk, hiszen az Esztergomban letelepedett Suzukinak több hazai 
beszállítója található ebben a körzetben, s folytathatnánk a sort a Móron letelepedett autóipari vállaikozásokkal, ill. a Ford székesfehérvári gyárával.

Elemei:

- a régióban letelepedett autógyárak, azok közvetlen beszállítói,

- az autógyártás második, harmadik vonalához tartozó - általában a külföldi, közvetlen beszállítók hazai és külföldi beszállítói,

- az autóiparhoz, szélesebb körben a gépgyártáshoz kapcsolódó termelỏ szolgáltatók, mint pl. karbantartó, kutató-fejlesztő, informatikai és egyéb vállalkozások.

A nemzetközi ipartelepítési tendenciáknak megfelelỏen állítható, hogy a klaszter megerösődése a jövőben tovább fokozódik, hiszen a nyugati jármügyártók továbbra is folytatják az élobmunka igényes termelési fázisok "olcsóbb bérủ országokba" történó áthelyezését, ill. álláspontunk szerint előbb vagy utóbb meg fog jelenni a régióban az igazán tökeintenzív fejlesztés is. Ebben a vonatkozásban utalni szeretnénk az AUDI Györben létesíteni tervezett motorfejlesztó laboratóriumára, ill. a KNORR BREMSE budapesti fejlesztő központjára.

\section{Elektronikai és elektrotechnikai ipari klaszter}

A kirajzolódó klaszter jellegét és méretét tekintve is kisebb, mint az elöző pontban tárgyalt autóalkatrész- és gépjármúipari csoportosulás. Az elektronikai és elektrotechnikai vállalkozások inkább szigetszerüen jelennek meg a térségben, fơbb csomósodási pontjai Székesfehérváron, Tatabányán és Veszprémben találhatók. Természetesen ezen központok kisugárzó hatása majdnem az egész régióban érezhető.

Elemei:

- kitüntetett és központi szerepet tölt(het) be a VIDEOTON és az általa nyújtott integrált gyártási szolgáltatások, ill. ezt a cél szolgálja a holding aktív régióbeli terjeszkedési politikája is,

- a térségben letelepedett nemzetközi vállalkozások (pl. IBM, Philips), ill. a hozzájuk kapcsolódó beszállítók

A klaszter fejlődését meghatározzák a nevezett vállalkozások, ill. a majdan letelepülő vállalkozások, valamint a hozzájuk kapcsolódó, kisebb szolgáltató cégek. Tekintettel arra, hogy a magyar elektronikai és informatikai szakemberek kiválóan megállják helyưiket a világ vezető vállalatainál, az ágazat további dinamikus növekedése prognosztizálható. Figyelembe kell azonban venni azt, hogy ezen a területen rendkívül nagy összegủ beruházások szükségesek, föképpen a termelés tekintetében, hiszen azt néhány nagy világcég uralja (pl. hardvergyártás). A különféle informatikai, programozási és tesztelési szolgáltatások azonban lehetőséget nyújtanak a hazai kis- és középvállalkozások számára is a klaszterhez kapcsolódáshoz.

Vegyipar, mũanyag-feldolgozás

Meg lehet kockáztatni a vegyipar, ill. a műanyag-feldolgozóipar önálló klaszterként való megjelölését is, azonban fontos hangsúlyozni az ágazat nagy mértékủ kötỏdését az autóiparhoz, valamint az elektronikai iparhoz.

Bázisát elsősorban a Veszprémhez, ill. térségéhez kötődő vállalkozások jelentik. 


\section{Ajánlások, jovaslatok}

A beszállitások elméleti hátterének áttekintése és az esettanulmányok alapján levonható következtetések szerint lényeges, hogy a térség vállalkozásai közötti sokirányú együttmüködés, fejlett és széles körü beszállitói kapcsolatok, ill. ezek tartós hálózata alakuljon ki.

Fontos ismételten hangsúlyozni, hogy a modern iparban a megbizható minôség, a szállítási határidók és egyéb követelmények maradéktalan teljesitése alapvetỏ kritérium. Ugyanis a növekvó termelékenységre és a csökkenö önköltségre épülő árak mellett csak folyamatos fejlesztésekkel, a szervezeti tanulás különbözó formáinak igénybevételével tartható csak fenn a vállalkozások versenyképessége, ellenkezõ esetben pedig veszélybe kerülhet beszállítói pozíciójuk.

Korábbi kutatások és az általunk végzett empirikus vizsgálatok bebizonyitották, hogy a regionális területfejlesztési stratégián belül is önálló programként lehetne kezelni a regionális beszállítói kapcsolatok, együttmükodések kezelését, a szervezŏdő hálózatok segitését.

Ehhez azonban elengedhetetlennek látszik, hogy megfelelö képünk legyen a beszállitók és a beszállitói kapcsolatok helyzetéröl. Ezen munka részben már meg is kezdődött, hiszen a Magyar Vállalkozásfejlesztési Alapítvány (MVA) hálózatához tartozó központok, alapítványok, illeszkedve a Kormányzat (a korábbi Ipari, Kereskedelmi és Idegenforgalmi Minisztérium koordinálásával megkezdődött) beszállítói célprogramjához a saját megyéjük területén felmérést végeznek a beszállítóként egyáltalán szóba jơhetó vállalkozások áttekintéséről. Ez egyfajta szữő tevékenység, amelyet a tervek szerint a kiválasztott potenciális beszállító cégek szakmai (elsősorban oktatási, minőségtanúsítási felkészitése) fog követni. Az MVA beszállítói programjának stratégiai célja:

- az exportképes termékek növelése, az import kiváltása,

- a hazai gyártású termékekben a hozzáadott érték növelése,

- a hazai gyártású termékekben az innováció és a kutatás-fejlesztési "hányad" növelése,

- a kis- és középvállalkozások gyártó- beszállítói pozíciójának erösitése,

- munkahelyteremtés és megtartás.

Lényeges azonban megállapítani azt is, hogy az említett célprogram csak három ágazatot (gép- és jármüipart, fémmegmunkálást; az elektronikai és elektrotechnikai ipart; valamint a müanyag- és gumiipart) fog át, amit a tervek szerint a későbbiekben fognak kiszélesíteni. Éppen ezért tartjuk lényegesnek a területfejlesztési stratégia keretén belül - a gazdasági kamarákra, az MVA hálózatához tartozó szervezetekre támaszkodva -, hogy a gazdálkodó szervezetek, kiemelten a kis- és középvállalkozások kapjanak információkat a potenciális partnerekról, a beszállítókat keresők követelményeiröl. Ehhez kapcsolódóan meg kell szervezni a képzést, tanácsadást, tapasztalatcserét, felhasználva a partnerközvetítés Magyarország számára is rendelkezésre álló nemzetközi fórumait.

Az európai programok (Román 1995) figyelembevételével nemcsak országos, de helyi szinten is figyelemmel kell kísérni, hogy milyen pozitiv vagy negativ hatást gyakorolnak a bevezetni kivánt új rendeletek, szabályok - elsősorban önkormányzati szinten. 
Különösen fontosnak tartjuk az Európai Unióban kidolgozott "Regionális Innovációs Stratégiảk $(R I S)^{\prime \prime}$ adaptációját és a hazai régiókban történö kimunkálását, mert a tapasztalatok szerint azok hatása már rövidtávon megjelenik.

Megfontolandó a közjogi kamarák közre- és együttmüködésével, adott esetben pénzügyi támogatásával a beszállítások esetén szóba jöhető vállalkozások szakmai szövetségeinek, ill. a jelenlegi és potenciális beszállító vállalatok által létrehozandó szervezetek segitése; regionális vállalatcsoporti hálózatok kiépitése, amelyek a kamarák területi szerkezetéhez igazodva, azokon belül szakmák szerint elkülönülve nyújtanának integrációs keretet a kis- és középvállalkozások számára. Nemzetközi tapasztalatok szerint ugyanis a beszállítói kapcsolatok és hálózatok építésének, fejlesztésének fö bázisát ezek a piaci alapon müködö, s az egyes vállalkozások között létrejövő formális és informális kapcsolatok alkotják. Éppen ezért a regionális fejlesztési stratégiában érdekelt szervezetek akkor töltik be leghatékonyabban feladatukat, ha a vállalkozások közötti kommunikációt, kapcsolatfelvételt, információközvetitést és a konkrét igényekre alapozva az oktatást, szakmai továbbképzést meg tudják szervezni, és le tudják bonyolítani.

\section{Jegyzetek}

' A tanulmány "A Kơzép-Dunántúl terủletfejlesztési koncepciója" c. kutatás keretében készült, amelyet a Kơzép-Pannon Regionális Fejlesztési Társaság Rt. támogatott.

2 Megjegyezzuk, hogy az utóbbi egy-két évben Magyarországon megfigyelt bruttó hazai termék (GDP) nơvekedésért szinte kizárólagosan néhány multinacionális vállalat (IBM, PHILIPS, AUDI, SUZUKI, TUNGSRAM stb.) magyar uzemei felelösek (Matolcsy 1997). Ez onmagában nem is lenne probléma, de ezen multinacionális vállalkozások termelésúk bövitéséhez nem magyar vállalkozások szolgáltatásait veszik igénybe, csupán szigetszerü nơvekedési pólusokat alkotnak, s nem járulnak hozzá a magyar régiók dinamizálásához.

${ }^{3}$ A minőségbiztosítási tanúsítvány és az auditált minőségbiztosítási rendszer megléte alapvető kơvetelmény ("ugródeszka") a beszállítói tárgyalások megkezdéséhez, minden egyéb feltétel csak ezután kơvetkezik.

${ }^{4}$ Természetszerüleg mindez a korábbi beszállitók ellenállásába uttkỏzik és ök mindent meg fognak tenni annak érdekében, hogy továbbra is az adott gyár beszállitói maradjanak. Érdekes a német beszállító vállalatok példája, amelyek nem nagyon türik, hogy pl. a BMW vagy a Daimler-Benz számára más külföldi cég szállítson, és mindent elkővetnek a nevezett gyárak vezetésénél, hogy továbbra is ök maradjanak a kedvezményezettek, sốt akkor is beszállítók maradnak, ha számukra ezen piaci szegmens veszteséget hoz. Ebböl a példából is látszik, hogy mennyire lényeges neves cégek beszállítójának lenni, hiszen ez egyfajta garanciát is jelent további partnereik számára, akiken azután megkeresik az elmaradt profitot.

${ }^{5}$ Ma Gazdasági Minisztérium.

${ }^{6}$ A megkérdezett vállalkozások a következök voltak: Ajka Kristály Üvegipari Kft., ALCOA-FUJIKURA LIMITED HUNGARY Kft, ARTESIN Kft. (ZYTEC Kft.), ASG Gépgyártó Kft., Bakony Müvek Autóalkatrészgyártó Rt., Balaton Bútorgyár Rt., BOWDEN Kft., Emerson Electric Magyarország Kft., Garzon Bútor Rt., GASZTROMETÁL Gép és Berendezésgyártó Rt., IBM Storage Products Kft., IKARUS MÓRI ALKATRÉSZGYÁRTÓ Kft., ITT Automotive Magyarországi Kft., Le Belier Magyarország Formaöntöde Rt., LEAR CORPORATION HUNGARY Kft., MACHER Gépészeti és Elektronikai Kft., Magyar Alumínium Rt., Magyar Suzuki Rt., Móritech Kft., NORIT Kozmetikai Kft., Payer Industries, PHILIPS Végszerelö Központ Magyarország Kft., R\&M ALUFE Fémszerkezeti Kft., ROBIX Hungary Kft., Székesfehérvári Metál Fék- és Kơszőrügépgyár Rt., TULIPÁN Ruhaipari Rt., Uni Montex Kft., Videoton Holding Rt.

${ }^{7}$ Hivatkozva a kis számú mintára, az elemzés során a hangsúlyt a vállalatok észrevételeire, javaslataira helyeztuk, hiszen ilyen alacsony elemszámnál a statisztikai módszerek alkalmazása torzítaná a mondanivalót. 


\section{Irodalom}

Bagó E. (1991) A nagy- és kisvállalatok kapcsolata. Közgazdasági Szemle, 9. sz.

Dusek T. (1997) A területfejlesztés megújítási iránya, az ipari körzetek. In: Az ipar, a kereskedelem és az idegenforgalom regionális szintủ fejlesztésének hazai feltételrendszere és alapvető harmonizációs feladatai az EU csatlakozásból adódóan. (kézirat), Készült az Ipari, Kereskedelmi és Idegenforgalmi Minisztérium megbízásából. MTA RKK NYUTI, Győr, I-18. o.

Enyedi Gy. - Rechnitzer J. (I987) Az innovációk tárbeli terjedése a magyar mezógazdaságban. In: Tér és Társadalom, 4. 69-88. o.

Horváth Gy. (szerk.) (1993) Régiók és városok az olasz modernizációban. MTA RKK, Pécs 384. o.

Horváth Gy. (szerk.) (1997) Régiók felemelkedése és hanyatlása. Regionális átalakulás a brit szigeteken. MTA RKK, Pécs 440。 0.

Hrubi L. (1994) A Dél-Dunántúl gazdaságszerkezete és ipara. In: Tér és Társadalom 1-2. 83-107. o.

Káldor M. (1989) Az Egyesult Királyság lassú nővekedésének okai. In: A gazdaságelmélet - gazdaságpolitika. KJK, Budapest 156-186. o.

Korompai A. (199I) Innovációs parkok és terjedési folyamatok szerepe a területfejlesztésben (kézirat) 22. 0 .

Matolcsy Gy. (1997) Innováció és kis- és középvállalati fejlesztési stratégia. In: Tanulmányok a kis- és kőzépvállalkozások fejlesztési stratégiájáról. OMFB, Budapest, 13-4I. o.

Nikodémus A. (199I) Az innovációterjedés fóldrajzi modelljei. In: Aula l. sz.

Nikodémus A. - Ruttkay É. (1994) A gazdasági modernizáció elemei a hazai regionális fejlódésben. Kandidátusi értékezés, Budapest

Rechnitzer J. (1994) A regionális gazdasági növekedés elméletei. In: Fejezetek a regionális gazdaságtan tanulmányozásához (Szerk.: Rechnitzer), MTA RKK, Györ-Pécs, I42-167. o.

Román Z. (1995) Beszállitások a feldolgozóiparban. Közgazdasági Szemle 12. 1165-1176. o.

\section{POSSIBLE NETWORKS OF SUPPLIERS AND INDUSTRIAL COOPERATION IN THE MID- TRANSDANUBIAN REGION}

\section{TIBOR DŐRY}

Nowadays, the issue of networks of suppliers and industrial cooperation is given a special attention. So far, in the fields of regional economics and spatial planning in Hungary, there has been no attempt to analyse the structures of zones of innovation, the complex processes of modern industrial change and the territorial aspects of flexible production systems within any Hungarian region. The article tries to address this challenge, on the one hand by applying some of the modern theories of economics and on other hand by analysing the empirical data of my interviews with company leaders in the Mid-Transdanubian region. These interviews were conducted for the purpose of setting up a complex regional development plan for the above-mentioned region. The analysis of networks of suppliers and industrial cooperation in Hungary after 1989, the comparison with European Union practises and the experiences of the companies in the region together may actively contribute to the improvement of networks of industrial cooperation. On the basis of theoretical investigation on the structures of networks of suppliers and industrial cooperation and the results of my empirical research, it should be noted that to catalyse regional development in any region, there needs to be existing a multilevel, developed and wide-ranging web of supplier networks and industrial cooperations. 
As a result of our research, we would like to conclude that it is necessary to set up various chambers and alliances of companies which participate or will participate in the regional networks of suppliers and industrial cooperations. These alliances and chambers should cooperate in building up new alliances between various economic actors, creating innovation strategies for regional development, producing and passing on information concerning different companies in the given region and in organising professional trainings and courses on the basis of the needs of the regional actors. 